Environmental research funding Bleak outlook

The UK Natural Environment Research Council (NERC) is struggling against the somewhat cool attitude of the Minister of State for the Environment, Mr Michael Heseltine, towards science. The Chief Scientist's office at the Department of the Environment (DoE) is doing its best to protect NERC from budget cuts, but the task is not proving easy.

In fact, the department's attitude was so discouraging late last year that even NERC's chairman, the sanguine $\mathrm{Sir}$ Hermann Bondi, was beginning to be worried. When Bondi took up his post in October 1980 he defended those of Heseltine's cuts which were already affecting NERC, in the name of the "Rothschild principle" - that the customer (in this case DoE) pays for what it wants and the contractor (NERC) provides it. After more than a year's experience of DoE attitudes, however, Sir Hermann's line has softened a little: "I still believe in the Rothschild principle" he says, "but Rothschild assumed that there would be enlightened customers taking a long view".

The problem for NERC does not seem to lie in fundamental, or in applied research, but in the "strategic research" which is not obviously one or the other. A prime example is the geological survey of Great Britain, whose science may appear to be uninspiring, and which is applied only occasionally for major construction projects. In the long run, however, it provides a basic data set without which much other work would not be possible.

DoE's attitude has pushed NERC into finding more commercial contracts both in the United Kingdom, and abroad; but, say NERC staff, contracts in the United Kingdom cannot supplant the geological survey because they are too patchy, too specific and often entail a degree of commercial secrecy. Moreover, British firms are at least as short of cash as the government at present. Abroad, NERC have been seeking contracts actively, but without any major successes. Bondi would like to encourage this kind of expansion, but NERC is relatively new in the field and must compete with seasoned operators like the US Geological Survey and the Institute du Physique du Globe of Paris.

In the meantime, NERC staff must be supported - and the problem has been compounded by DoE delays in defining a programme of research for 1982-83. By early April, NERC would normally have expected to know DoE's requirements for the year. Worse, the council has been told not to spend money on the basis of DoE "letters of intent" until everything is signed and sealed, a further break with the usual practice.

However, there is some light at the end of the environmental tunnel. Recently NERC held a top level meeting with its three main customer departments, those of energy, industry and environment and with the Central Policy Review Staff (the Cabinet's think tank) and there was a consensus that the problems lay with strategic research and long range planning.

NERC staff argued that if only they could be told the requirements of the departments well in advance, then the council could design a good basic and strategic research programme which would also yield the contractual results that the departments wanted. So the departments will work together to produce a five-year forward look for NERC, with the intention that this would be "rolled forward" annually thereafter.

Robert Walgate

\section{NERC stays afloat}

The British government has allowed the Natural Environment Research Council (NERC) one present: a new ship, specially designed for research, to replace Shackleton which is now a creaking 28 years old. The vessel is being bought on a loan from a merchant bank, and will cost NERC about $£ 1$ million a year for eight years out of its current $£ 56$ million budget.

The ship will be called Charles Darwin. It will not be ice strengthened, but will have a clear aft deck for equipment and will be able to tow over the stern, a big simplification over Shackleton (a converted container ship) which has to pull equipment from an A-frame over the starboard side. The Charles Darwin will be fitted for general research from marine biology to geophysics, and will provide the largest on-board laboratories of the NERC fleet. It should be delivered in 1984 .

The research fleet will then include: Discovery, also a general purpose research ship, which must retire around 1989; the marine biological ships Frederick Russell and Challenger; and two ice-strengthened vessels. There are three other English research ships owned by the Ministry of Agriculture, Fisheries and Food (for fisheries research).

Robert Walgate

\section{US recombinant DNA guidelines Expected change} Washington

Continuing the trend towards relaxing controls on the newly commercial business of recombinant DNA research, the National Institutes of Health (NIH) has published revised guidelines that govern most US academic research and some industry research in the field. There are few surprises in the new guidelines; they follow the plan voted by NIH's Recombinant Advisory Committee (RAC) meeting in February (see Nature 4 February, p.358).

The revised guidelines (published in the
Federal Register, 21 April and effective from that date) contain three important features. First, although there was pressure to abandon the present system of mandatory controls and change to a voluntary system, the mandatory system was retained. This means that organizations performing recombinant DNA research must still each have an institutional biosafety committee, and, for those doing work at P3 and P4 containment levels, a biological safety officer.

Second, no class of experiments is "prohibited" any longer. Of the five classes of experiments that were prohibited under the old guidelines, three are still required to undergo RAC review and NIH approval before initiation. These are drug resistance traits, toxin genes and deliberate release to the environment. Third, the section of the guidelines dealing with containment levels has been drastically simplified. Many experiments previously requiring NIH approval now require only the approval of the local biosafety committee.

In approving these guidelines, Richard M. Krause, Director of the National Institute of Allergy and Infectious Diseases of NIH, rejected a proposal for far greater relaxation of controls put forward last April by Dr Allan Campbell and Dr David Baltimore. These would have required a major overhaul of the guidelines. Apparently, Krause agrees with the majority of the members of RAC that such an overhaul is not appropriate - yet.

\section{Deborah Shapley}

\section{UK nuclear power}

\section{Cracks no worry}

New design criteria for the pressure vessel for a British pressurized water reactor ( $P W R$ ) has been given the cautious approval of Britain's most distinguished PWR opponent, metallurgist Sir Alan Cottrell, now Master of Jesus College at the University of Cambridge.

The new criteria are the result of the work of the United Kingdom Atomic Energy Authority study group, headed by Sir Walter Marshall, on the integrity of PWR pressure vessels. The group last reported in 1976 , but six years later the situation requires a fresh look. The design of the Sizewell PWR is going ahead; there have been changes in methods of steel manufacture; and there is now an accumulation of evidence and experience of stress corrosion cracking and of catastrophic failure tests.

In an open letter to Sir Walter Marshall, Sir Alan writes: "I would expect us to avoid the problems of localized cracking, underneath the stainless steel cladding, which the French have experienced in some of their vessels",

He adds "Whether we shall be entirely clear of the problems of metal fatigue and 